\title{
The Itasca Community College Engineering - Condensed Scheduling Effects on Persistence and Time to Graduation
}

\author{
Bart Johnson, Ron Ulseth \\ Itasca Community College Engineering
}

\begin{abstract}
Groups within and outside engineering education are interested in student success rates and time to graduation for engineering students in order to meet the nation's need for new engineering graduates. In 2002 Itasca Community College's Engineering program changed from a traditional 16 week semester to a "block scheduling" format with classes taught "one-at-a-time" in 4 weeks and then in the Spring of 2005 to a "two-at-a-time" in 8 weeks. This scheduling method is successful in providing students the ability to navigate through the pre-calculus and calculus sequences at different paces than in a traditional schedule yet have the ability to complete their engineering degree in four years. Students who have started their engineering education at Itasca in the block scheduling format average 8.7 semesters to completion of their bachelor's degree in engineering with graduation rates higher than many comparable to institutions across the nation at $54 \%$
\end{abstract}

\section{Introduction}

Throughout the nation there are many efforts underway to increase student success rates and reduce time to graduation for engineering students in order to meet the nation's needs for engineering. Itasca's part of this effort led to utilizing block scheduling to increase student success rates and reduce time to graduation regardless of starting math course. For a majority of engineering programs, the calculus math sequence is the key factor in the time to graduation due to the prerequisites required for engineering and physics courses. For a student to complete their engineering degree in four years, they need to start in calculus 1 in the fall of their first year and successfully complete all of their math and other STEM courses on the first attempt and in a specified order.

This study analyzes the impact of condensed scheduling on graduation rate and time to graduation in Itasca Community College's engineering program. The study looks at two groups at Itasca:

- 4-Week Block Group - Students who started in the Fall of 2002 and Fall of 2003 and had a majority of their STEM classes taught in a 4-week block format

- 8-Week Block Group - Students who started in the Fall of 2004 and Fall of 2005 and had a majority of their STEM classes taught in a 8-week block format 


\section{Background}

Itasca Community college (ICC) is a small (1000 FYE), two-year college located in Grand Rapids, Minnesota about 80 miles northwest of Duluth, Minnesota. It was founded in 1922 and has held accreditation with the North Central Association Higher Learning Commission since the mid 1970's. ICC primarily serves students located in the northern third of the state. ICC is a member of the Minnesota State Colleges and Universities system (MnSCU) as well as a member of the Northeast Minnesota Higher Education District (NHED). The college offers a number of two year transfer and terminal programs. The college is exceptionally known (regionally and nationally) for its associate of science engineering transfer program.

The ICC engineering program is an open admissions program with approximately $1 / 3$ of the student body ready to start their math sequence with calculus $1,1 / 3$ with pre-calculus, and $1 / 3$ at a math course below pre-calculus. The program's faculty consists of 6 engineering/physics instructors, 2 math instructors, and 1.5 chemistry instructors. The program has grown from 10 students in 1993 to 150 students in 2010 (Ulseth 2004).

Students who complete ICC's engineering program then transfer to 4-year institutions across the nation to complete their STEM degree. A majority of the students transfer to the regional institutions with engineering programs with which Itasca has strong partnerships and articulation agreements:

- Bemidji State University

- Michigan Technological University

- Minnesota State University, Mankato Main Campus

- Minnesota State University, Mankato Iron Range Engineering Campus
- North Dakota State University

- University of Minnesota - Duluth

- University of Minnesota - Twin Cities

- University of North Dakota

- St. Cloud State University

\section{ICC Engineering's Condensed Course Model}

The majority of classes at ICC are the traditional 16-week semester courses, while classes in ICC's engineering program (engineering, math, chemistry, and physics courses) are currently delivered in a "two classes at a time" 8-week block format with two eight week blocks per semester. Students generally take two engineering, math, or science classes per block while completing one or two semester long general education courses. Each block class is scheduled for 2 hours per day, 5 days a week with flexibility for the instructor to provide "float" or noncontact days to allow for student work days or engineering program events. This scheduling format has the following attributes:

- Focus on two engineering, math, or science courses at a time

- Flexible two hour class setting to create an interactive and student-led learning environment

- Ability to complete more than one math or physics course in a semester

The ability to take more than one math or physics course in a semester provides students with the ability to "catch up" to their peers in their STEM courses. Traditionally a student who tests into 
a pre-calculus course is a semester, if not a year, behind in the four year curriculum due to the math prerequisite requirements for first and second year physics and engineering courses; most importantly with the calculus 1 prerequisite. There are a multitude of scenarios for math course sequences for a student based on a student's starting math course, performance in a particular course and potential scheduling issues such as full courses, which can cause a delay in the completion of a STEM degree in four years.

Prior to the 8-week block format students learned in a 4-week block format with one STEM class at a time with a total of 9 STEM courses in a year. The class schedule changed to an 8-week format in 2005 to address potential concerns with scheduling, illness issues, and classroom utilization.

\begin{tabular}{|c|c|c|c|c|c|c|}
\hline \multirow[b]{2}{*}{$\frac{\text { Starting Math }}{\text { Course }}$} & \multicolumn{6}{|c|}{ Math Courses by Semester } \\
\hline & Fall 1st Year & Spring 1st Year & Fall 2nd Year & Spring 2nd Year & Fall 3rd Year & Spring 3rd Year \\
\hline Calculus 1 & Calculus 1 & Calculus 2 & $\begin{array}{c}\text { Multi-Variable } \\
\text { Calculus }\end{array}$ & $\begin{array}{l}\text { Differential } \\
\text { Equations }\end{array}$ & & \\
\hline Pre-Calculus & Pre-Calculus & Calculus 1 & Calculus 2 & $\begin{array}{c}\text { Multi-Variable } \\
\text { Calculus }\end{array}$ & $\begin{array}{c}\text { Differential } \\
\text { Equations }\end{array}$ & \\
\hline $\begin{array}{l}\text { Calculus } 1 \text { - } \\
\text { with Calculus } 1 \\
\text { repeated }\end{array}$ & Calculus 1 & Calculus 1 & Calculus 2 & $\begin{array}{c}\text { Multi-Variable } \\
\text { Calculus }\end{array}$ & $\begin{array}{l}\text { Differential } \\
\text { Equations }\end{array}$ & \\
\hline $\begin{array}{c}\text { Intermediate } \\
\text { Algebra }\end{array}$ & $\begin{array}{c}\text { Intermediate } \\
\text { Algebra }\end{array}$ & Pre-Calculus & Calculus 1 & Calculus 2 & $\begin{array}{c}\text { Multi-Variable } \\
\text { Calculus }\end{array}$ & $\begin{array}{l}\text { Differential } \\
\text { Equations }\end{array}$ \\
\hline
\end{tabular}

Table 1: Sample Math Course Sequences in Traditional Semester Model

\begin{tabular}{|c|c|c|c|c|c|c|c|c|}
\hline \multirow[b]{3}{*}{$\frac{\text { Starting Math }}{\text { Course }}$} & \multicolumn{8}{|c|}{ Math Courses by Semester } \\
\hline & \multicolumn{2}{|c|}{ Fall 1st Year } & \multicolumn{2}{|c|}{ Spring 1st Year } & \multicolumn{2}{|c|}{ Fall 2nd Year } & \multicolumn{2}{|c|}{ Spring 2nd Year } \\
\hline & $\begin{array}{c}\text { 1st } 8 \text { Week } \\
\text { Block }\end{array}$ & $\begin{array}{c}\text { 2nd 8 Week } \\
\text { Block }\end{array}$ & $\begin{array}{c}\text { 1st } 8 \text { Week } \\
\text { Block }\end{array}$ & $\begin{array}{c}\text { 2nd } 8 \text { Week } \\
\text { Block }\end{array}$ & $\begin{array}{c}\text { 1st } 8 \text { Week } \\
\text { Block }\end{array}$ & $\begin{array}{l}\text { 2nd } 8 \\
\text { Week } \\
\text { Block }\end{array}$ & $\begin{array}{c}\text { 1st } 8 \text { Week } \\
\text { Block }\end{array}$ & $\begin{array}{l}\text { 2nd } 8 \\
\text { Week } \\
\text { Block }\end{array}$ \\
\hline Calculus 1 & & Calculus 1 & Calculus 2 & & $\begin{array}{l}\text { Multi- } \\
\text { Variable } \\
\text { Calculus }\end{array}$ & & $\begin{array}{c}\text { Differential } \\
\text { Equations }\end{array}$ & \\
\hline Pre-Calculus & Pre-Calculus & & Calculus 1 & Calculus 2 & $\begin{array}{l}\text { Multi- } \\
\text { Variable } \\
\text { Calculus }\end{array}$ & & $\begin{array}{c}\text { Differential } \\
\text { Equations }\end{array}$ & \\
\hline $\begin{array}{l}\text { Calculus } 1 \text { - with } \\
\text { Calculus } 1 \\
\text { repeated }\end{array}$ & & Calculus 1 & Calculus 1 & Calculus 2 & $\begin{array}{l}\text { Multi- } \\
\text { Variable } \\
\text { Calculus }\end{array}$ & & $\begin{array}{c}\text { Differential } \\
\text { Equations }\end{array}$ & \\
\hline $\begin{array}{l}\text { Intermediate } \\
\text { Algebra }\end{array}$ & $\begin{array}{l}\text { Intermediat } \\
\text { e Algebra }\end{array}$ & Pre-Calculus & Calculus 1 & Calculus 2 & $\begin{array}{l}\text { Multi- } \\
\text { Variable } \\
\text { Calculus }\end{array}$ & & $\begin{array}{c}\text { Differential } \\
\text { Equations }\end{array}$ & \\
\hline
\end{tabular}

Table 2: Sample Math Course Sequences in ICC Engineering's 8 Week Block Format 
Tables 1 and 2 show the impact that block scheduling has on the ability for students to stay on a path to graduating in four years regardless of starting math class or any need to repeat a class. The scheduling itself only allows for the opportunity for students to stay on a four year track. The impact was similar in the 4-week block format. The next question is how students perform in terms of graduation rate and semesters to completion of their four year engineering degree given the condensed course models.

\section{Data}

All students who started ICC's Introduction to Engineering courses from the Fall 2002 to present date have been tracked to evaluate their success in the condensed course format. For the 241 students who started at Itasca in the Fall of 2002 through Fall of 2005 the following data was collected:

- Starting Math Course

- Successful Completion of Calculus 1

- Successful Completion of Physics 1

- Transfer Institution

- Degree Obtained at Transfer Institution

- Total Semesters for Completion of Bachelor's Degree in Engineering

The data was collected through transcript reviews and follow-up contacts with each of the students. The data was then compiled to evaluate:

- Graduation rates overall

- Graduation rates based upon starting math course

- Graduation rates for students who started Physics 1

- Graduation rates based upon starting math course grade

- Average semesters to graduation

\section{Results}

\begin{tabular}{|c|c|c|c|c|c|c|c|}
\hline \multirow[b]{2}{*}{ Starting } & \multirow[b]{2}{*}{ \# of Students } & \multirow[b]{3}{*}{$\underline{\text { STEM }}$} & \multirow[b]{2}{*}{$\frac{\% \text { Completion }}{\text { of STEM }}$} & \multirow[b]{2}{*}{ Start Physics 1} & \multicolumn{3}{|c|}{ Number of Semesters to Graduation } \\
\hline & & & & & & Pre-Calc or Int. & Regardless \\
\hline Academic & Starting Intro & & Bachelors & \& Completion of & $\underline{\text { Calculus } 1 \text { as }}$ & $\underline{\text { Algebra as } 1 \mathrm{st}}$ & of 1st Math \\
\hline Year & to Engineering & Degrees & Degree & Degree & 1st Math Course & Math Course & Course \\
\hline 2002 & 60 & 39 & $65 \%$ & $80 \%$ & 8.5 & 8.9 & 8.7 \\
\hline 2003 & 39 & 25 & $64 \%$ & $78 \%$ & 8.8 & 8.7 & 8.7 \\
\hline 2004 & 75 & 34 & $45 \%$ & $68 \%$ & 8.9 & 9.2 & 9.0 \\
\hline 2005 & 67 & 33 & $49 \%$ & $77 \%$ & 8.5 & 8.6 & 8.5 \\
\hline Overall & 241 & 131 & $54 \%$ & $75 \%$ & 8.7 & 8.9 & 8.7 \\
\hline
\end{tabular}

Table 3: Results of the ICC Engineering Block Schedule

The results show that the ICC engineering block model is a success. The overall average degree completion rate of $54 \%$ is higher than the degree completion rates found in other national studies: 
- $40.8 \%$ degree completion in engineering/engineering technologies for students entering STEM field in 1995-96 as of 2001 in Engineering (Chen 2009)

- $45 \%$ and $49 \% 6$ year graduation rates for male and female students, respectively, starting for Southeastern University and College Coalition for Engineering Education (SUCCEED) Institutions (SUCCEED institutions award over 1/12 of all U.S. engineering degrees) (Borrego, Padilla, Zhang, Ohland, \& Anderson, 2005)

- 38\% in 6 year graduation rate in STEM for students starting in Fall 1993 in the Center for Institutional Data Exchange and Analysis (C-IDEA) study (Tan, 2002)

- $21 \% 4$ year STEM graduation rate for students starting in Fall 2005 at Wright State University (Klingbeil 2010)

In comparison to these national studies, the ICC engineering program model is more successful in producing students who complete their Bachelor's degree in engineering. ICC's success is despite an open admissions policy with a majority of the students below calculus 1 ready in math preparation and other factors that would classify them as "at-risk" students. In addition, the students must then transfer after their two years at Itasca and deal with the issues associated with transferring to a new institution.

In addition to the higher success rate, the students are completing their degrees in a shorter amount of time. Itasca students average 8.7 semesters to completion of their STEM degree regardless of starting math course and Itasca's open admission policy. The data also shows there is no significant difference in average semesters to completion between students with calculus 1 as their first math course and those with a lower starting math course. Figure one compares the 4, 5, and 6 year graduation rates for the Fall 2002 class at Itasca with the Fall 1996 class at the SUCCEED institutions (Borrego, Padilla, Zhang, Ohland, \& Anderson, 2005).

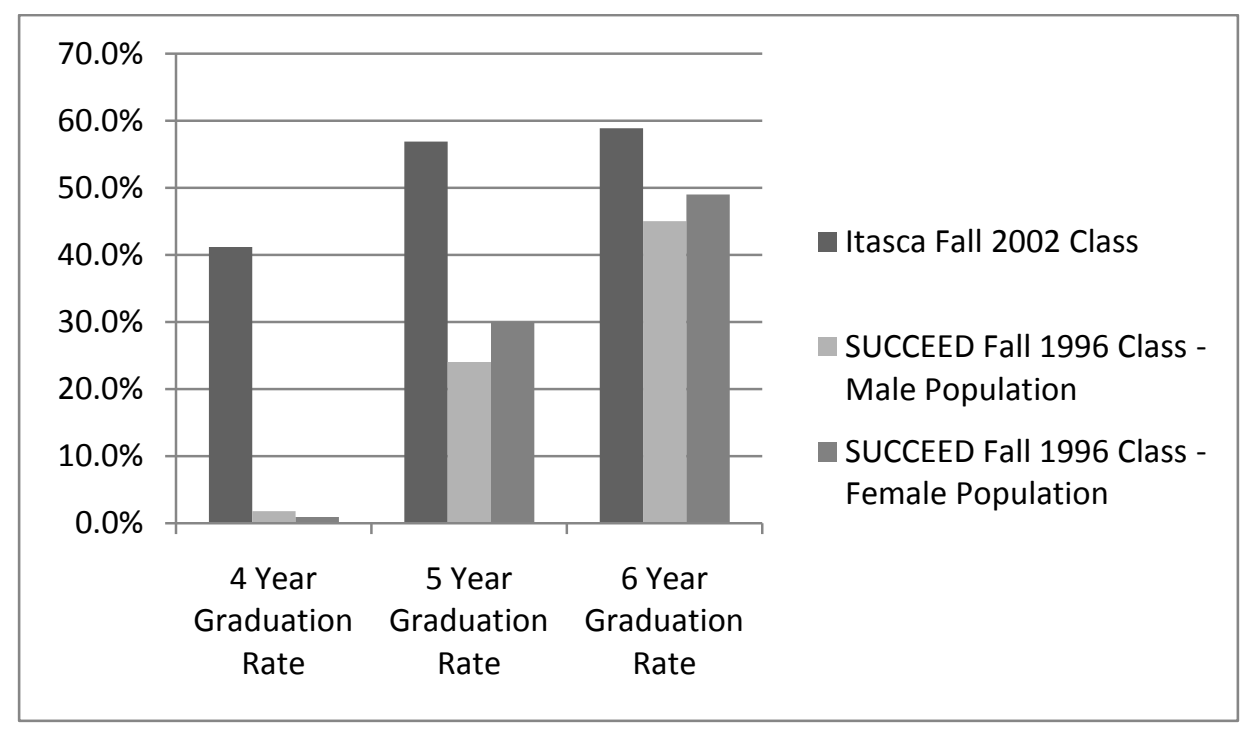

Figure 1: Comparison of 4, 5, \& 6 Year Graduation Rates of Itasca and SUCCEED Students

As shown in Figure 1, the success of the Itasca model in providing a pathway for the students to complete their degree in 4 years is evident in comparison to the SUCCEED institutions. 
In addition to the condensed class schedule at Itasca, other key attributes of the ICC engineering program that contribute to the student success are:

- Student centered learning environment

- A very strong and vibrant faculty and student learning community

Another noteworthy finding is the decrease in degree completion rate as ICC's engineering program transitioned from a 4-week to an 8-week condensed course model. Possible reasons for this decrease are:

- Decreased sense of focus on learning with multiple courses being taken at one time

- Reduced sense of a small cohort for each class

\section{Future Work}

Although the findings from this study are encouraging for the condensed block formatting at Itasca, there is still some additional work needed:

- Study of comparison groups at Itasca's partner 4 year institutions

- Study of ICC students prior to the condensed block format

- Investigation into combining a more progressive model for math education, such as the Wright State University model, into ICC's condensed class format

- Investigation to effect of student learning in small cohorts

- Continued investigation into more data on national averages for time to completion of degree

\section{Conclusion}

The condensed course format of Itasca Community College's engineering program has been very successful with high student graduation rates (54\%) for students achieving a bachelor's of science in engineering in a short time frame ( 8.7 semester average) despite the students starting with a wide spectrum of math placements and then transferring to other institutions to complete their degree. This model is transferable to other institutions and can serve to increase the number of students finishing an engineering degree. The model can be fully adopted or could be used for select courses, such as math, and still function within a traditional 16 week class format The potential for the ICC two year engineering model to transform engineering education is significant due to the fact that $42.0 \%$ of degrees granted in engineering/engineering technologies are for students who started a 2-year public institution according to the July 2009 US Department of Education report "Students Who Study Science, Technology, Engineering, and Mathematics (STEM) in Postsecondary Education" (Chen 2009) 


\section{References}

Borrego, M., Padilla, M., Zhang, G., Ohland, M., Anderson, T., (2005). Graduation Rates, Grade-Point Average, and Changes of Major of Female and Minority Students, Proceedings from $35^{\text {th }}$ ASEE/IEEE Frontiers in Education Conference October 19-22, 2005, Indianapolis, IN Session T3D IEEE\# 0-7803-9077-6/05

Chen X. (2009), Students Who Study Science, Technology, Engineering, and Mathematics (STEM) in Postsecondary Education, Department of Education, National Center for Education Statistics, 1996/01 Beginning Postsecondary Students Longitudinal Study

Klingbeil, N., June 2010 Presentation on "The Wright State Model for Engineering Mathematics Education" at Itasca Community College

Tan, David L. (2002). Majors in Science, Technology, Engineering, and Mathematics, Gender and ethnic Differences in Persistence and Graduation, NSF Grant \#REC9903426 Report

Ulseth, R. (2004). From Nothing to Something, Proceedings from Advancing Science, Serving Society (AAAS) Invention and Impact: Building Excellence in Undergraduate Science, Technology, Engineering and Mathematics (STEM) Education, April 2004, Washington, D.C. 